\title{
Traditional "Congklak" Games and Cooperative Character in Mathematics Larning
}

\author{
Kamid1, Syaiful2 ${ }^{*}$, Roselii Theis ${ }^{3}$, Sufri ${ }^{4}$, Sabila Eka Septi5 , Rido Ilham Widodo ${ }^{6}$
}

1,2,3,4,5,6 Faculty of Teaching and Education, Universitas Jambi, Jambi, Indonesia

\section{ART ICLE INFO}

Article history:

Received June 08, 2021

Revised June 11, 2021

Accepted July 26, 2021

Available online August 25, 2021

\section{Kata Kunci:}

Permainan Tradisional, Karakter Kerja Sama, Matematika

\section{Keywords:}

Traditional Games, Cooperative Characters, Math

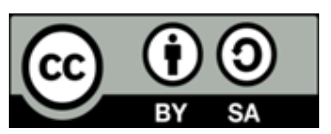

This is an open access article under the CC BY-SA license.

Copyright $(2021$ by Author. Published by Universitas Pendidikan Ganesha.

\begin{abstract}
A B S T RAK
Matematika merupakan salah satu materi yang tidak disukai oleh sebagian besar siswa. Selain kurang menarik, siswa sekolah dasar juga cenderung memiliki kesenjangan nilai di antara teman-temannya. Hal ini menunjukkan kurangnya kerjasama yang diterapkan dalam pembelajaran matematika. Tujuan penelitian ini adalah untuk menganalisis hubungan dan pengaruh karakter kerjasama dengan respon siswa dengan menggunakan permainan tradisional dalam pembelajaran. Jenis penelitian ini menggunakan metode kuantitatif dengan jenis penelitian komparatif. Penelitian ini dilakukan dengan menyebarkan kuesioner. Teknik analisis data yang digunakan adalah random sampling. Subjek penelitian dalam penelitian ini adalah 120 siswa. Hasil yang diperoleh adalah karakter kooperatif dalam permainan tradisional congklak lebih unggul yang berada pada persentase sangat baik (60\%). Respon siswa terhadap permainan tradisional congklak sangat baik (55\%). Hasil uji korelasi karakter kooperatif siswa dalam permainan tradisional yaitu terdapat hubungan antara karakter kerjasama dengan respon siswa terhadap permainan tradisional congklak pada mata pelajaran matematika. Dapat disimpulkan bahwa terdapat hubungan dan pengaruh karakter kerjasama dengan respon siswa. Implikasi dari penelitian ini adalah bermain permainan tradisional dalam pembelajaran dapat meningkatkan minat siswa dalam belajar matematika.
\end{abstract}

\section{A B S T R A C T}

Mathematics is one material that most students do not like. In addition to being less attractive, elementary school students also tend to have grades among their peers. This shows the lack of attention applied in learning mathematics. This study aimed to analyze the relationship and influence of cooperative characters with student responses by using traditional games in learning. This type of research uses quantitative methods with the type of comparative research. This research was conducted by distributing questionnaires. The data analysis technique used is random sampling. The research subjects in this study were 120 students. The results obtained are that the cooperative character in the traditional game of Congklak is superior, which is in a very good percentage $(60 \%)$. The student's response to the traditional game of congklak was very good $(55 \%)$. The results of the correlation test of the cooperative character of students in traditional games, namely, there is a relationship between the character of cooperation with students' responses to the traditional game of congklak in mathematics. It can be said that there is a relationship and influence of the character of cooperation with student responses. The implication of this research is that playing traditional games in learning can increase students' interest in learning mathematics.

\section{INTRODUCTION}

21st century learning as a period of knowledge aims to meet the needs of life in various knowledge-based contexts and 21st century learning is introduced as a period of knowledge (Chai \& Kong, 2017; Lubis, 2018; Munoto, 2018). 21st Century Learning is also learning that integrates literacy skills, knowledge skills, skills and attitudes, and mastery of technology (Hirschman \& Wood, 2018; Rusdin, 2018). Education in the 21st century is becoming increasingly important to ensure students have learning skills. These 21 skills are relevant to the four pillars of education which include learning to know, learning 
to do, learning to be and learning to live together (Gelen Assoc, 2018; Gürsoy, 2021). Therefore, students are expected to have great motivation to always learn to deepen their knowledge which is always evolving from time to time. One of the knowledge that must be possessed by students is mathematics.

Mathematics is one of the basic sciences that has an important role both in everyday life and in the development of science and technology (Hamdi et al., 2018; Nugroho et al., 2018). Basic mathematics learning can hone students' mathematical abilities to think logically, analyze, critically and systematically by improving the learning process (Hobri et al., 2018; Nurlaily et al., 2019). Mathematics requires soft skills and perspectives to solve and solve problems (Hendriana et al., 2018; Ambussaidi \& Yang, 2019; Lin et al., 2020). One of the materials in mathematics is the material for the nets of cubes and blocks. In solving difficult materials, it is necessary to develop creativity in learning mathematics by integrating a model of developing creativity in the teaching and learning process of mathematics. However, the current problem is that many children have low mathematical abilities (Kowiyah \& Mulyawati, 2018; Mullis et al., 2012). Students feel that mathematics is a complex subject (Areepattamannil et al., 2015; Stojanović et al., 2021). Based on previous research, it was also stated that when students took part in learning, they felt bored and had difficulty understanding mathematics subject matter (Hassan et al., 2016; Kowiyah et al., 2019). This has an impact on students' common mathematical knowledge.

One way that makes it easier for students to learn mathematics is to play by learning. One of the traditional games that can be used in learning is Congkak. Traditional games are relatively simple games but provide tremendous benefits if we explore the meaning of the game in depth (Kusumawati \& Ambarsari, 2021; Nurwahidah et al., 2021). The traditional game of congklak is a traditional game that has existed for a long time and has many benefits for children. Congklak game is a game played by two children, using a congklak board, which has 16 holes, has congklak seeds which are usually small stones, shells, plant seeds or marble seeds and the holes in the congklak board are the same diameter, but 2 the farthest hole is larger as an ovary or home for players to collect congklak seeds (Budianti, 2021; Humairo \& Amelia, 2021; Susilawati et al., 2021). Through playing congklak children will get benefits that can develop basic mathematical abilities, for example by playing congklak children are able to distinguish concepts full of blanks, mention the results of additions, connect two sets of objects, number by pointing at objects, show the order of objects for numbers up to 10, connect or pair symbol of numbers with objects (Mualik et al., 2020; Purwanti, 2020). So it can be concluded that by using congklak children can practice their numeracy skills. This game will also foster a cooperative character in students.

Character education is a conscious and sincere effort from teachers to instill values in students. People with character are those who try to do their best for God Almighty, themselves, other people, the environment of their country and country by making full use of their potential (knowledge) and accompanied by awareness and emotions (feelings) (Grummich et al., 2017; Liang et al., 2021). Education aims to improve the quality of implementation and educational outcomes in schools that lead to the formation of character and noble character in students as a whole, integrated and adapted to graduate competency standards (Basri, 2017; Rachmadyanti, 2017; Primayana, 2019). Character education is a conscious and sincere effort from teachers to instill values in students (Birhan et al., 2021; Prasetyo et al., 2020). Through education, students are expected to be able to independently improve and use their knowledge, examine character and apply values. Character education is a conscious and sincere effort from teachers to instill values in students (Agnies zka Bates, 2019; Asmi et al., 2018; Lian et al., 2020). People with good character are those who try to do their best for God Almighty, himself, other people, the environment, the country and his country by making full use of the potential (science) created and accompanied by awareness and emotions (feelings).

Cooperation is a joint effort between individuals or groups to achieve common goals (Burik, 2021; Kazu \& İș, 2018; Ozan, 2019). Just as the school's goal is to create the characteristics of an effective school, a school that has the main features include: strong instructional leadership, high expectations of student achievement, an orderly and comfortable learning environment, emphasizing basic skills. In line with educational goals, good cooperation will produce good goals (Devi et al., 2020; Smith et al., 2018; Weng \& Chen, 2020). Collaboration between students and training students to be able to control emotions, foster scientific attitudes and of course have an impact on maximum learning outcomes (Nordgren et al., 2021; Pershina et al., 2019; Troussas et al., 2020). Can reveal that cooperation is very important for elementary school students to assist in the learning process and in other fields. Research is similar to previous research about the cooperative character of students (Apriansyah et al., 2017). However, previous studies did not compare the character of cooperation with student responses. In addition, previous studies did not perform some of the tests carried out in this study. Previous research also did not test correlation and regression. On student responses to the traditional game of congklak in mathematics (Mualik et al., 2020; Purwanti, 2020; Syahputri et al., 2021). However, previous studies did not compare the character of cooperation with students' responses to the traditional game of congklak in mathematics. 
It is also the same with research on the character of student cooperation, research on student responses also does not carry out the tests carried out in this study, namely regression and correlation tests. The regression test works to determine the effect of the character of cooperation with student responses. The correlation test conducted in this study was to determine the ability to solve problems closely with students' beliefs in questions, because students' beliefs in solving problems will affect student learning outcomes (Utami \& Wutsqa, 2017). So it can be said that previous research did not test some of the tests carried out by this study. The urgency in this study is very important because there has been no research that has examined the cooperative character of the traditional congklak game and student responses. In addition, this research also works to see how important students' responses to the cooperative character of traditional games (congklak) are in three elementary schools at once. This study aimed to analyze the relationship and influence of cooperative characters with student responses by using traditional games in learning. It is expected that students are more interested in learning the material, and also traditional games can grow students' character. collaboration with students

\section{METHOD}

This type of research uses a quantitative method with a comparative type. The data obtained using numerical data with a Likers scale 5 . This study gains an understanding of the phenomenon from a basic logic, usually covering the study population. Quantitative research which is divided into comparative and i using survey procedures. Survey research is a quantitative research procedure wherein administering a survey on a sample or on an entire population design to describe attitudes, opinions, behaviors, or specific characteristics of a population (Creswell, 2012). The instrument in this study used an observation sheet, namely the character of cooperation and student responses to the traditional game of congklak on mathematics subjects. There are 18 valid statements. This instrument uses a Likert scale. A scale consisting of 5 points with a very good score of 5 , good that is 4 , which is 3 , not good that is 2 , and not good is 1. Each statement is representative of each indicator of interest. Each statement is representative of each indicator. The observation sheet grid instrument used in this study is as Table 1.

Table 1. Instruments Grid observation sheet character cooperation and student responses to the traditional game Congklak on mathematics subjects

\begin{tabular}{llll}
\hline No & Indikator & No Butir & Jumlah \\
\hline 1 & Student interest in TPS type cooperative learning & $1,2,3^{*}$ & 3 \\
2 & $\begin{array}{l}\text { The benefits obtained by students during learning by using } \\
\text { the TPS type of cooperative learning model }\end{array}$ & $4,5,6,7,8,9$ & 6 \\
3 & $\begin{array}{l}\text { Constraints experienced during the TPS type cooperative } \\
\text { learning process }\end{array}$ & $10^{*}, 11^{*}, 12^{*}, 13^{*}$, & 6 \\
& $\begin{array}{l}\text { Students' Expectations and Suggestions for the TPS Type } \\
\text { Cooperative Learning Process }\end{array}$ & $16,17,14^{*}$ & 3 \\
\hline
\end{tabular}

Source: (Putri, 2017)

The population of this study was 120 students from three schools, namely SD IT Ash-Shidiiqi, SD Islam As'ad, and SDN 220/IV Telanaipura Jambi City. The sampling technique is total sampling. The subjects taken were each school consisting of 40 students from 40 students in SD IT Ash-Shidiiqi, 40 students in SD Islam As'ad, and 40 students in SDN 220/IV Telanaipura.The sample in this study uses the Probability Sampling sampling technique, which is a sampling technique that provides equal opportunities for each member (element) of the population to be selected as a sample member (Achdiyat \& Utomo, 2018). The reason for using the purposive sampling technique is that not all samples have criteria that match the phenomenon under study. Therefore, the authors chose a purposive sampling technique which stipulates certain considerations or criteria that must be met by the samples used in this study. The total number of samples that will be used in this study are students of SD IT Ash-Shidiiqi, SD Islam As'ad, and SDN 220/IV Telanaipura.

This research was carried out starting from distributing questionnaires or questionnaires, then analyzing quantitative data, then identifying the results for follow-up. At the data collection stage, questionnaires were given to 120 students in three schools, namely SD IT Ash-Shidiiqi, SD Islam As'ad, and SDN 220/IV Telanaipura. From the data, data analysis is then carried out, namely data coding, filtering appropriate data and analysis of the data. The data analysis technique used is sampling. The sampling technique was adopted because it provides unbiased parameter estimates and is better if the population is homogeneous (Alsabahi et al., 2021; Bankole \& Nasir, 2020; Tao \& Ning, 2018). Using sampling can 
reduce the potential for bias in the selection of cases to be included in the sample. Due to the homogeneity of the population, the sampling frame is clear and general in nature. This research was carried out starting from distributing observation sheets, then analyzing quantitative data, then identifying the results for follow-up. At the data collection stage, questionnaires were given to 120 students at SD IT Ash-Shidiiqi, SD Islam As'ad, and SDN 220/IV Telanaipura. From this data, data analysis was carried out, namely data coding, filtering appropriate data and analysis of the data. that. In describing the data in the form of attitudes and science process skills of students, the statistics used are descriptive and inverential statistics. The description or presentation of large amounts of data that includes the mean, mode, median, maximum, minimum, and standard deviation is a descriptive statistic. Inverential in the form of correlation test. Then test for normality and linearity. Then the data were analyzed using SPSS 26 program to obtain the percentage, frequency, mean and standard deviation. With this random sampling condition, data deviation is carried out. In data collection, the first activity that must be done is to select students based on the categories given by the researcher, then provide an observation sheet for the character of cooperation and student responses to the traditional game of congklak on mathematics subjects. Then the questionnaire data was processed using the SPSS application. The use of the SPSS application functions to view descriptive statistics, in the form of mean, min, max, percentage, and category of students. The data needed in research can be collected or obtained from various data sources.

\section{RESULT AND DISCUSSION}

\section{Result}

The following describes the results of descriptive statistics on the character of cooperation and student responses to the traditional game of Congklak on Mathematics. Where the results obtained from the distribution of observation sheets to three elementary schools, namely SD IT Ash-Shidiiqi, SD Islam As'ad, SDN 220/IV Telanaipura. Based on the results of data analysis, it can be concluded that the cooperative character in the traditional game of congklak at SDN 220/IV Telanaipura is superior to SD IT Ash-Shidiiqi and SD Islam As'ad. Proven in a very good percentage of $60 \%$. Based on the results of data analysis, the students' responses to the traditional congklak game at SDN 220/IV Telanaipura were superior to that of SD IT Ash-Shidiiqi and SD Islam As'ad. proved the percentage is very good, namely $55 \%$. Based on the results, it can be opened that the data is normally distributed. The normality test is obtained with the Kolmogorov-Smoirnov test, the significance value is $>$ from 0.05 . Based on the result, it can be concluded that the linearity test on student responses has a linear relationship between SD IT AshShidiiqi, SD Islam As'ad, and SDN 220/IV Telanaipura. It is proved that the result of sig is more than 0.05.

The correlation test for the cooperative character of students in the traditional game of Congklak on mathematics subjects that there is a relationship between the character of cooperation and student responses to the traditional game of congklak on mathematics subjects. It is proved that the results of Sig. (2-tail) $<0.05$. The regression test for the character of student cooperation in the traditional game of Congklak on subjects is shown the results obtained are sig $<0.05$ and it can be said that the cooperative character variable affects the student response variable. The correlation value (R) is 0.651 and the coefficient of determination obtained from the square of the $\mathrm{R}$ value. From the output displayed on SPSS, the coefficient of determination is 0.657 , which means that the influence of the perception variable on students' cooperation skills is $65.7 \%$ and the rest $34.3 \%$ is influenced by other variables.

\section{Discussion}

One of the traditional games, namely the Congklak game in mathematics, can train students to hone their numeracy skills and foster students' cooperative character. Learning by playing makes learning activities fun so that students feel the learning atmosphere becomes more active (Kusuma et al., 2021; Prensky, 2001; Widyari et al., 2018). Activities like this can bridge student interactions with other students. Learning activities are one of the keys to success that determine learning success (Boso et al., 2021; Coppola et al., 2019; Wilson et al., 2020). Learning while playing involves heterogeneous group members. The success of work in cooperative learning is strongly influenced by the involvement and role of each member. In addition, they were learning while playing also increases the cooperative character of students (Danniels et al., 2020; Kristjánsdóttir et al., 2018).

The character of cooperation is the main character that needs to be instilled in students (Haryono, 2020; Leonard \& Nwanekezi, 2018). The character of cooperation is essential for every student at the elementary school level. Collaboration between students to control emotions, foster scientific attitudes, and, of course, impact maximum learning outcomes (Daulay et al., 2019; Khan \& Masood, 2015). With the implementation of this research, it can be seen that student interest dramatically influences the character of student cooperation in learning. The character of cooperation is very influential in traditional games implemented in mathematics subjects (Qusyairi \& Sakila, 2018; Rabgay, 2018). Cooperative learning 
makes students actively participate in learning activities (Demitra \& Sarjoko, 2018; Suherti \& Tsuroya, 2019). Students become active in working together and help each other among group members to succeed. It makes student learning activities optimal (Nurhusain, 2017; Turgut \& Turgut, 2018).

This research is in line with previous research about the cooperative character of students (Pratiwi \& Nugrohoseno, 2017; Sari, 2017). However, previous research did not link the cooperative character with student responses in mathematics in elementary school. In addition, previous studies did not perform several tests carried out in this study, one of which was to test correlation and regression and the indicators used were limited. Regression test serves to determine the effect of the character of cooperation with student responses. The correlation test conducted in this study was to determine the ability to solve problems closely with students' beliefs about the questions, because students' beliefs in solving problems will affect student learning outcomes (Utami \& Wutsqa, 2017). This research is also in line with other previous research about students' responses to the traditional game of congklak in mathematics (Mualik et al., 2020; Syahputri et al., 2021). It's just that previous studies did not compare the character of cooperation with student responses to the traditional game of Congklak so that the effect of the response could not be known. So it can be said that previous research is not as clear and detailed as this research.

The implication of this research is that playing traditional games in learning can increase students' interest, especially in learning mathematics. In this study, it was found that students' responses to mathematics learning which were implemented with the congklak game were very good. This is very influential in growing students' cooperative character in learning mathematics. Thus, learning mathematics that is implemented with the game congklak is very effective for elementary school students. The limitation of this research is that it only uses cooperative character variables and learning response models, but testing with other variables such as achievement results has not been carried out. Where achievement results are very important to be a benchmark for the success of a learning model carried out in elementary schools for mathematics subjects. So that variables such as achievement results to be tested in further research. The researcher suggests to conduct further research to compare the variable character of cooperation and student response with other variables such as achievement results and the researcher suggests to conduct research at the elementary school level.

\section{CONCLUSION}

Based on the formulation of the problem in the research, the conclusion obtained is that there is a relationship between cooperative characters and student responses at SD IT Ash-Shidiiqi, SD Islam As'ad, and SDN 220/IV in the traditional game of Congklak in mathematics subjects and there is an effect of cooperation with student responses at SD IT Ash-Shidiiqi, SD Islam As'ad, and SDN 220/IV to the traditional game of congklak in mathematics.

\section{REFERENCES}

Achdiyat, M., \& Utomo, R. (2018). Kecerdasan Visual-Spasial, Kemampuan Numerik, dan Prestasi Belajar Matematika. Formatif: Jurnal Ilmiah Pendidikan MIPA, 7(3), 234-245. https://doi.org/10.30998/formatif.v7i3.2234.

Agnies zka Bates. (2019). Character education and the 'priority of recognition. Cambrid Ge Journal of Educatio N, 49(6), 695-710. https://doi.org/10.1080/0305764X.2019.1590529.

Alsabahi, M. A., Maisurah, K., Bahador, K., \& Saat, R. M. (2021). Cogent Business \& Management The influence of personal characteristics and workplace learning on information technology competency among external auditors: The role of organisational culture as a moderator The influence of personal characteristics and wo. Cogent Business \& Management, 8(1). https: //doi.org/10.1080/23311975.2021.1899625.

Ambussaidi, I., \& Yang, Y.-F. (2019). The Impact of Mathematics Teacher Quality on Student Achievement in Oman and Taiwan. International Journal of Education and Learning, 1(2), 50-62. https://doi.org/10.31763/ijele.v1i2.39.

Apriansyah, B., Sulaiman, \& Mukarromah, S. B. (2017). Kontribusi Motivasi, Kerjasama, Kepercayaan Diri terhadap Prestasi Atlet Sekolah Sepakbola Pati Training Center di Kabupaten Pati. Journal of Physical Education and Sports, 6(2), 101-107. https://doi.org/10.15294/jpes.v6i2.17358.

Areepattamannil, S., Melkonian, M., \& Khine, M. S. (2015). International note: Exploring differences in native and immigrant adolescents' mathematics achievement and dispositions towards mathematics in Qutar. Journal 40. https://doi.org/10.1016/j.adolescence.2014.12.010.

Asmi, A. R., Dhita Surbakti, A. N., \& C., H. (2018). E-Module Development Based Flip Book Maker For 
Character Building In Pancasila Coursework Sriwijaya University. Jurnal Pendidikan Ilmu Sosial, 27(1), 1-10. https://doi.org/10.17509/jpis.v27i1.9395.

Bankole, Q. A., \& Nasir, Z. (2020). Empirical Analysis of Undergraduate Students ' Perception in the Use of Electronic Sources in Kwara State University Library. International Information \& Library Review, O(0), 1-11. https://doi.org/10.1080/10572317.2020.1805274.

Basri, I. (2017). Evaluasi Pembelajaran Sekolah Dasar (SD) Berbasis Pendidikan Karakter dan Multikultural. Jurnal Ilmiah Sekolah Dasar, 1(4), 247. https://doi.org/10.23887/jisd.v1i4.12593.

Birhan, W., Shiferaw, G., \& Tiruye, A. A. M. T. H. (2021). Exploring the context of teaching character education to children in preprimary and primary schools. Social Sciences \& Humanities Open, 4(1), 100171. https://doi.org/10.1016/j.ssaho.2021.100171.

Boso, C. M., van der Merwe, A. S., \& Gross, J. (2021). Students' and educators' experiences with instructional activities towards critical thinking skills acquisition in a nursing school. International Journal of Africa Nursing Sciences, 14, 100293. https://doi.org/10.1016/j.ijans.2021.100293.

Budianti, Y. (2021). Pengaruh Permainan Congklak dan Gatheng Terhadap Kecerdasan Logika Matematika Anak Usia Dini di RA Khiru Ummah. Jurnal Rudhah, 9(1), 93-108. https://doi.org/10.30829/raudhah.v9i1.945.

Burik, A. (2021). Using Technology to Help Students Set, Achieve, and Publicize Goals. Adult Literacy Education: The International Journal of Literacy, Language, and Numeracy, 3(1), 83-89. https: //doi.org/10.35847/aburik.3.1.83.

Chai, C. S., \& Kong, S.-C. (2017). Professional learning for 21st century education. Journal of Computers in Education, 4(1), 1-4. https://doi.org/10.1007/s40692-016-0069-y.

Coppola, A. M., Voils, A. L., Gafkjen, J., \& Hancock, D. J. (2019). Partnership Roles in Early-Learning Providers' Healthy Eating and Physical Activity Programs: A Qualitative Study. American Journal of Health Education, 50(3), 190-199. https://doi.org/10.1080/19325037.2019.1590262.

Creswell, J. W. (2012). Educational Research. University of Nebraska.

Danniels, E., Pyle, A., \& DeLuca, C. (2020). The role of technology in supporting classroom assessment in play-based kindergarten. Teaching and Teacher Education, 88. https: //doi.org/10.1016/j.tate.2019.102966.

Daulay, L. A., Hakim, H., \& Sartikawati, L. D. (2019). The Improvement Of Student's Mathematical Communication Ability By Using Cooperative Learning: Course Review Horay. Tarbiyah, 26(1). https://doi.org/10.30829/tar.v26i1.376.

Demitra, \& Sarjoko. (2018). Effects of Handep Cooperative Learning Based on Indigenous Knowledge on Mathematical Problem Solving Skill. International Journal of Instruction, 11(2), 103-114. https://doi.org/10.12973/iji.2018.1128a.

Devi, M., Annamalai, M. A. R., \& Veeramuthu, S. P. (2020). Literature education and industrial revolution 4.0. Universal Journal of Educational Research, 8(3), 1027-1036. https://doi.org/10.13189/ujer.2020.080337.

Gelen Assoc, I. (2018). European Journal of Education Studies Academicians' Predictions Of 21 St Century Education And Education In The 21 St Century. 4, 165-204. https://doi.org/10.5281/zenodo.1233478.

Grummich, P., Ganslandt, 0., Buchfelder, M., \& Roessler, K. (2017). Characterization of a Factual Knowledge-Associated Brain Memory Area by Functional Magnetic Resonance Imaging and Implementation in Tumor and Epilepsy Brain Surgery. World Neurosurgery, 107. https://doi.org/https://doi.org/10.1016/j.wneu.2017.07.176.

Gürsoy, G. (2021). Digital storytelling: Developing 21st century skills in science education. European Journal of Educational Research, 10(1), 97-113. https://doi.org/10.12973/EU-JER.10.1.97.

Hamdi, S., Suganda, I. A., \& Hayati, N. (2018). Developing higher-order thinking skill (HOTS) test instrument using Lombok local cultures as contexts for junior secondary school mathematics. Research and Evaluation in Education, 4(2), 126-135. https://doi.org/10.21831/reid.v4i2.22089.

Haryono, H. E. (2020). The Influence of Cooperative Learning Model Type Group Investigation Toward Results of Learning Science Materials of Students. Jurnal Ilmiah Pendidikan Fisika, 4(1), 1. https: //doi.org/10.20527/jipf.v4i1.1772.

Hassan, S. R., Rosli, R., \& Zakaria, E. (2016). The Use of i-Think Map and Questioning to Promote HigherOrder Thinking Skills in Mathematics. Creative Education, 07(07), 1069-1078. https: //doi.org/10.4236/ce.2016.77111.

Hendriana, H., Johanto, T., \& Sumarmo, U. (2018). The role of problem-based learning to improve students' mathematical problem-solving ability and self confidence. Journal on Mathematics Education, 9(2), 291-299. https://doi.org/10.22342/jme.9.2.5394.291-300. 
Hirschman, K., \& Wood, B. (2018). 21st century learners: Changing conceptions of knowledge, learning and the child. The New Zealand Annual Review of Education, 23(June), 20. https://doi.org/10.26686/nzaroe.v23i0.5280.

Hobri, Septiawati, I., \& Prihandoko, A. C. (2018). High-order thinking skill in contextual teaching and learning of mathematics based on lesson study for learning community. International Journal of Engineering and Technology(UAE), 7(3), 1576-1580. https://doi.org/10.14419/ijet.v7i3.12110.

Humairo, V. M., \& Amelia, Z. (2021). Peningkatan Kemampuan Berhitung Awal Melalui Modifikasi Bentuk Permainan Congklak. Jurnal Anak Usia Dini Holistik Integratif (AUDHI), 3(1), 19. https://doi.org/10.36722/jaudhi.v3i1.589.

Kazu, İ. Y., \& İş, A. (2018). An Investigation About Actualization Levels of Learning Outcomes in Early Childhood Curriculum. Journal of Education and Training Studies, 6(3), 66. https://doi.org/10.11114/jets.v6i3.2928.

Khan, F. M. A., \& Masood, M. (2015). The Effectiveness of an Interactive Multimedia Courseware with Cooperative Mastery Approach in Enhancing Higher Order Thinking Skills in Learning Cellular Respiration. Procedia - Social and Behavioral Sciences, 176, 977-984. https://doi.org/10.1016/j.sbspro.2015.01.567.

Kowiyah, K., Mulyawati, I., \& Umam, K. (2019). Conceptual Understanding and Mathematical Representation Analysis of Realistic Mathematics Education Based on Personality Types. AlJabar: Jurnal Pendidikan Matematika, 10(2), 201-210. https://doi.org/10.24042/ajpm.v10i2.4605.

Kowiyah, \& Mulyawati, I. (2018). An analysis of primary school students' representational ability in mathematics based on gender perspective. Journal of Physics: Conference Series, 948(1). https://doi.org/10.1088/1742-6596/948/1/012016.

Kristjánsdóttir, H., Erlingsdóttir, A. V., \& Saavedra, J. M. (2018). Psychological skills, mental toughness and anxiety in elite handball players. Personality and Individual Differences, 134(June), 125-130. https://doi.org/10.1016/j.paid.2018.06.011.

Kusuma, G. P., Suryapranata, L. K. P., \& Utomo, Y. (2021). Enhancing Historical Learning Using Role-Playing Game on Mobile Platform. Procedia Computer Science, 179. https://doi.org/10.1016/j.procs.2021.01.078.

Kusumawati, E., \& Ambarsari, R. Y. (2021). Implementasi Permainan Tradisional Untuk Mengontrol Sosial Emosional Selama Proses Pembelajaran Daring Pada Anak Usia .... BERNAS: Jurnal Pengabdian ..., 2(2), 524-529. https://doi.org/10.31949/jb.v2i2.923.

Leonard, N. C., \& Nwanekezi, A. U. (2018). Effects of Guided Inquiry and Task Hierarchy Analysis Model in Cooperative Learning Strategy on Chemistry Students' Performance in Imo State. European Scientific Journal, ESJ, 14(25), 54-62. https://doi.org/10.19044/esj.2018.v14n25p54.

Lian, B., Kristiawan, M., Ammelia, D., Primasari, G., Anggung, M., \& Prasetyo, M. (2020). Teachers' Model in Building Students' Character. Journal of Critical Reviews, 7(14), 927-932. https://doi.org/10.31838/jcr.07.14.165.

Liang, Q., Torre, J. de la, \& Law, N. (2021). Do background characteristics matter in Children's mastery of digital literacy? A cognitive diagnosis model analysis. Computers in Human Behavior, 122. https://doi.org/10.1016/j.chb.2021.106850.

Lin, S., Zhou, Y., \& Wijaya, T. T. (2020). Using hawgent dynamic mathematics software in teaching arithmetic operation. International Journal of Education and Learning, 2(1), 25-31. https://doi.org/10.31763/ijele.v2i1.97.

Lubis, A. H. (2018). Integrasi TIK Dalam Pengajaran Bahasa Inggris Di Indonesia Abad Ke-21: Mitos Dan $\begin{array}{llll}\text { Realita. } & \text { Cakrawala Pendidikan, } & 37(1), & 11-21 .\end{array}$ https://journal.uny.ac.id/index.php/cp/article/view/16738/pdf.

Mualik, S., Efendi, D. I., \& Permata, R. D. (2020). Meningkatkan Kemampuan Berhitung Dengan Media Biji Sawo Melalui Permainan Congklak Pada Anak Kelompok B KB Nurul Jadid Desa Miliwang Kacematan Kerek Kabupaten Tuban Tahun Pelajaran 2910/2020. Prosiding Seminar Nasional Penelitian Dan Pengabdian Masyarakat, 5(2), 212-216. http://prosiding.unirow.ac.id/index.php/SNasPPM/article/view/410.

Mullis, I. V., Martin, M. O., Minnich, C. A., Stanco, G. M., Arora, A., Centurino, V. A., \& Castle, C. E. (2012). TIMSS 2011 Encyclopedia: Education Policy and Curriculum in Mathematics and Science. In Pirls (Vol. 1). https://doi.org/10.6209/JORIES.2017.62(1).03.

Munoto, W. and. (2018). 21st centuries skill implication on educational system. IOP Conference Series Materials Science and Engineering, 296(1). https://doi.org/10.1088/1757- 899X/296/1/012036.

Nordgren, K., Kristiansson, M., Liljekvist, Y., \& Bergh, D. (2021). Collegial collaboration when planning and preparing lessons: A large-scale study exploring the conditions and infrastructure for teachers' 
professional development. Teaching and Teacher Education, 108. https://doi.org/10.1016/j.tate.2021.103513.

Nugroho, P. B., Nusantara, T., As'ari, A. R., Sisworo, Hidayanto, E., \& Susiswo. (2018). Critical Thinking Disposition: Students Skeptic in Dealing with Ill-Logical Mathematics Problem. International Journal of Instruction, 11(3), 635-648. https://doi.org/10.12973/iji.2018.11343a.

Nurhusain, M. (2017). Impact Analysis of Cooperative Learning Model Application Type Two Stay Two Stray (Tsts) Toward Learning Outcomes of Mathematics. JPMI (Jurnal Pendidikan Matematika Indonesia), 2(2), 46. https://doi.org/10.26737/jpmi.v2i2.220.

Nurlaily, V. A., Soegiyanto, H., \& Usodo, B. (2019). Elementary school teacher's obstacles in the implementation of problem-based learning model in mathematics learning. Journal on Mathematics Education, 10(2), 229-238. https://doi.org/10.22342/jme.10.2.5386.229-238.

Nurwahidah, Maryati, S., Nurlaela, W., \& Cahyana. (2021). Permainan Tradisional Sebagai Sarana Mengembangkan Kemampuan Fisik Motorik Anak Usia Dini. PAUD Lectura: Jurnal Pendidikan Anak Usia Dini, 4(02), 49-61. https://doi.org/10.31849/paud-lectura.v4i02.6422.

Ozan, C. (2019). The effect of authentic assessment on academic achievement and attitude towards educational measurement and opinions of prospective teachers. International Journal of Evaluation and Research in Education, 8(2), 299-312. https://doi.org/10.11591/ijere.v8i2.18564.

Pershina, R., Soppe, B., \& Thune, T. M. (2019). Bridging analog and digital expertise: Cross-domain collaboration and boundary-spanning tools in the creation of digital innovation. Research Policy, 48(9). https://doi.org/https://doi.org/10.1016/j.respol.2019.103819.

Prasetyo, G., Hidayatullah, M. F., Akhyar, M., Wiranto, \& Perdana, R. (2020). Strengthening Students' Character Through Multimedia Learning In Primary Schools Education: Systematic LiteraturPrasetyo, G., Hidayatullah, M. F., Akhyar, M., Wiranto, \& Perdana, R. (2020). Strengthening Students' Character Through Multimedia Learning In . Humanities \& Social Sciences Reviews, 8(3), 268-277. https://doi.org/10.18510/hssr.2020.8328.

Pratiwi, W. K., \& Nugrohoseno, D. (2017). Pengaruh Kepribadian Terhadap Kerjasama Tim Dan Dampaknya Terhadap Kinerja Karyawan. Jurnal Bisnis Dan Manajemen, 2(031), 62-72. https://doi.org/10.26740/bisma.v7n1.p63-72.

Prensky, M. (2001). Fun, play and games: What makes games engaging. Digital Game-Based Learning, 5(1), 5-31. https://doi.org/10.31695/IJASRE.2018.33016.

Primayana, K. H. (2019). Menciptakan Pembelajaran Berbasis Pemecahan Masalah Dengan Berorientasi Pembentukan Karakter Untuk Mencapai Tujuan Higher Order Thingking Skilss (HOTS) Pada Anak Sekolah Dasar. Purwadita: Jurnal Agama Dan Budaya, 3(2), 85-92.

Purwanti, R. (2020). Peningkatan Kemampuan Berhitung Permulaan Melalui Permainan Tradisional Congklak (TK Dharma Wanita Kedunggalar Ngawi Tahun Ajaran 2018/2019). Jmece, 01(01), 4554. http://ejournal.stkipmodernngawi.ac.id/index.php/JMECE/article/view/159.

Putri, H. L. (2017). Peningkatan Karakter Kerja Sama Berbasis Layanan Bimbingan Klasikal Dengan Pendekatan Metode Proyek. In respository (Vol. 549). Universitas Sanata Dharma.

Qusyairi, L. A. H., \& Sakila, J. (2018). Pengaruh Model Cooperative Learning Tipe Inside-Outside Circle (IOC) terhadap Prestasi Belajar dengan Memperhatikan Minat Belajar Matematika. Palapa: Jurnal Studi Keislaman Dan Ilmu Pendidikan, 6(1), 34-49. https://doi.org/10.36088/palapa.v6i1.57.

Rabgay, T. (2018). The effect of using cooperative learning method on tenth grade students' learning achievement and attitude towards biology. International Journal of Instruction, 11(2), 265-280. https://doi.org/10.12973/iji.2018.11218a.

Rachmadyanti, P. (2017). Penguatan Pendidikan Karakter Bagi Siswa Sekolah Dasar Melalui Kearifan Lokal. Jurnal Pendidikan Sekolah Dasar, 3(2), 201-214. https://doi.org/10.30870/jpsd.v3i2.2140.

Rusdin, N. M. (2018). Teachers' Readiness in Implementing 21st Century Learning. International Journal of Academic Research in Business and Social Sciences, 8(4), 1271-1284. https: //doi.org/10.6007/IJARBSS/v8-i4/4270.

Sari, Y. (2017). Peningkatan kerjasama di sekolah dasar. Jurnal Administrasi Pendidikan, 1(1), 307-461.

Smith, R. O., Scherer, M. J., Cooper, R., Bell, D., Hobbs, D. A., Pettersson, C., Seymour, N., Borg, J., Johnson, M. J., Lane, J. P., Sujatha, S., Rao, P. V. M., Obiedat, Q. M., MacLachlan, M., \& Bauer, S. (2018). Assistive technology products: a position paper from the first global research, innovation, and education on assistive technology (GREAT) summit. Disability and Rehabilitation: Assistive Technology, 13(5), 473-485. https://doi.org/10.1080/17483107.2018.1473895.

Stojanović, J., Petkovic, D., Alarifi, I. M., Cao, Y., Denic, N., \& Ilic, J. (2021). Application of distance learning in mathematics through adaptive neuro-fuzzy learning method. Computers \& Electrical Engineering, 93. https://doi.org/10.1016/j.compeleceng.2021.107270.

Suherti, H., \& Tsuroya, T. F. (2019). Implementasi Model Cooperative Learning Teknik Stad Untuk 
Meningkatkan Kemampuan Berpikir Kreatif Mengajar dalam Program Latihan Profesi. Jurnal Soshum Insentif, 2(1), 67-79. https://doi.org/10.36787/jsi.v2i1.49.

Susilawati, E., Puspitasari, D., Kusumadewi, F., \& Nuryanih, L. (2021). Modifikasi Permainan Tradisional Congklak Terhadap Kemampuan Berhitung Untuk Meningkatkan Perkembangan Kognitif Pada Anak Usia Dini Tahun 2020. Jurnal Mutiara Ners, 4(1), 24-30. https://doi.org/10.51544/jmn.v4i1.1297.

Syahputri, S., Studi, P., Matematika, P., Keguruan, F., Samudra, U., \& Meurandeh, J. (2021). Meningkatkan minat belajar perkalian Matematika dengan permainan congklak di SDN Sidorejo. Pros. SemNas Peningkatan Mutu Pendidikan, 2, 44-49.

Tao, H., \& Ning, J. (2018). Computation Randomized quasi-random sampling / importance resampling. Communications in Statistics - Simulation and Computation, o(0), 1-13. https: //doi.org/10.1080/03610918.2018.1547398.

Troussas, C., Krouska, A., \& Sgouropoulou, C. (2020). Collaboration and fuzzy-modeled personalization for mobile game-based learning in higher education. Computers \& Education, 144. https://doi.org/https://doi.org/10.1016/j.compedu.2019.103698.

Turgut, S., \& Turgut, I. G. (2018). The effects of cooperative learning on mathematics achievement in Turkey: A meta-analysis study. International Journal of Instruction, 11(3), 663-680. https://doi.org/10.12973/IJI.2018.11345A.

Utami, R. W., \& Wutsqa, D. U. (2017). Analisis kemampuan pemecahan masalah matematika dan selfefficacy siswa SMP negeri di Kabupaten Ciamis. Jurnal Riset Pendidikan Matematika, 4(2), 166. https://doi.org/10.21831/jrpm.v4i2.14897.

Weng, S. S., \& Chen, H. C. (2020). Exploring the role of deep learning technology in the sustainable development of the music production industry. Sustainability (Switzerland), 12(2), 1-20. https://doi.org/10.3390/su12020625.

Widyari, I. A. M., Ganing, N. N., \& Sri Asri, I. G. A. A. (2018). Pengaruh Model Pembelajaran Role Playing Berbantuan Teks Dialog Terhadap Kompetensi Keterampilan Berbicara Dalam Bahasa Indonesia. Mimbar Ilmu, 23(2), 95-103. https://doi.org/10.23887/mi.v23i2.16415.

Wilson, O. W. A. C. M. B., Papalia, Z., Duffey, M., \& Bopp, M. (2020). College Students' Experiences and Attitudes Toward Physical Activity Counseling. The Journal for Nurse Practitioners, 16(8). https://doi.org/10.1016/j.nurpra.2020.06.006. 